Marquette University

e-Publications@Marquette

School of Dentistry Faculty Research and

Publications

Dentistry, School of

$1-1-2015$

Effect of Additives on Mineral Trioxide Aggregate Setting Reaction Product Formation

Angela M.Zapf

Marquette University

Sharath C.V. Chedella

Marquette University

David W. Berzins

Marquette University, david.berzins@marquette.edu

Accepted version. Journal of Endodontics, Vol. 41, No. 1 (January 2015): 88-91. DOI. (C) 2015

American Association of Endodontists. Published by Elsevier Inc. Used with permission. 


\title{
Effect of Additives on Mineral Trioxide Aggregate Setting Reaction Product Formation
}

\author{
Angela M. Zapf \\ Department of General Dental Sciences-Dental Biomaterials, \\ Marquette University School of Dentistry, \\ Milwaukee, WI \\ Sharath C. V. Chedella \\ Department of General Dental Sciences-Dental Biomaterials, \\ Marquette University School of Dentistry, \\ Milwaukee, WI \\ David W. Berzins \\ Department of General Dental Sciences-Dental Biomaterials, \\ Marquette University School of Dentistry, \\ Milwaukee, WI
}

\begin{abstract}
Introduction: Mineral trioxide aggregate (MTA) sets via hydration of calcium silicates to yield calcium silicate hydrates and calcium hydroxide $\left(\mathrm{Ca}[\mathrm{OH}]_{2}\right)$. However, a drawback of MTA is its long setting time. Therefore, many additives have been suggested to reduce the setting time. The effect those additives have on setting reaction product formation has been ignored. The objective was to examine the effect additives have on MTA's setting time and setting reaction using differential scanning calorimetry (DSC).

Journal of Endodontics, Vol. 41, No. 1 (January 2015): pg. 88-91. DOI. This article is (c) Elsevier and permission has been granted for this version to appear in e-Publications@Marquette. Elsevier does not grant permission for this article to be further copied/distributed or hosted elsewhere without the express permission from Elsevier.
\end{abstract}


NOT THE PUBLISHED VERSION; this is the author's final, peer-reviewed manuscript. The published version may be accessed by following the link in the citation at the bottom of the page.

Methods: MTA powder was prepared with distilled water (control), phosphate buffered saline, 5\% calcium chloride $\left(\mathrm{CaCl}_{2}\right), 3 \%$ sodium hypochlorite $(\mathrm{NaOCl})$, or lidocaine in a 3:1 mixture and placed in crucibles for DSC evaluation. The setting exothermic reactions were evaluated at $37^{\circ} \mathrm{C}$ for 8 hours to determine the setting time. Separate samples were stored and evaluated using dynamic DSC scans $\left(37^{\circ} \mathrm{C} \rightarrow 640^{\circ} \mathrm{C}\right.$ at $\left.10^{\circ} \mathrm{C} / \mathrm{min}\right)$ at 1 day, 1 week, 1 month, and 3 months ( $n=9 /$ group/time). Dynamic DSC quantifies the reaction product formed from the amount of heat required to decompose it.

Thermographic peaks were integrated to determine enthalpy, which was analyzed with analysis of variance/Tukey test $(\alpha=0.05)$.

Results: Isothermal DSC identified 2 main exothermal peaks occurring at $44 \pm 12$ and $343 \pm 57$ minutes for the control. Only the $\mathrm{CaCl}_{2}$ additive was an accelerant, which was observed by a greater exothermic peak at $101 \pm 11$ minutes, indicating a decreased setting time. The dynamic DSC scans produced an endothermic peak around $450^{\circ} \mathrm{C}-550^{\circ} \mathrm{C}$ attributed to $\mathrm{Ca}(\mathrm{OH}) 2$ decomposition. The use of a few additives ( $\mathrm{NaOCl}$ and lidocaine) resulted in significantly less $\mathrm{Ca}(\mathrm{OH})_{2}$ product formation.

Conclusions: DSC was used to discriminate calcium hydroxide formation in MTA mixed with various additives and showed $\mathrm{NaOCl}$ and lidocaine are detrimental to MTA reaction product formation, whereas $\mathrm{CaCl}_{2}$ accelerated the reaction.

Key Words: Calcium hydroxide; differential scanning calorimetry; mineral trioxide aggregate; setting reaction; setting time

Mineral trioxide aggregate (MTA) was introduced to dentistry as a repair material for lateral root perforations. 1 Since that time, MTA has been used in many dental applications, with this influx of applications attributed to MTA's biocompatibility and sealing ability.., 3 Although these favorable properties remain MTA's strong suit, its long setting time has warranted improvements. MTA sets through an exothermic reaction, requiring hydration of its powder to produce the cement paste that matures over time. 4 The setting of MTA is best understood through examining the hydration reactions of its main constituent, Portland cement, in which the most important reactions are tricalcium silicate and dicalcium silicate reacting with water to produce calcium silicate hydrates (C-S$\mathrm{H})$ and calcium hydroxide $(\mathrm{Ca}[\mathrm{OH}] 2) \cdot \frac{5-7}{}$ Once MTA is fully hydrated, the $\mathrm{Ca}(\mathrm{OH})_{2}$ reaction product comprises approximately $10 \%-15 \%$ of the set cement. $\frac{7,8}{}$ The setting time of MTA has been documented to be 165 minutes. 9 45-140 minutes for the initial and final setting, 10 40-140 minutes for the initial and final setting, $\underline{11} 50$ minutes, $\underline{12} 151$ minutes, $\underline{13}$ and $220-$ 250 minutes. $\underline{14}$ Traditionally, resistance to penetration in the form of Gillmore and Vicat needles has been used to assess the setting time of cements. Although these methods are inexpensive and easy to use, they are somewhat subjective and perhaps reflect the variation in reported setting times. More importantly, they provide little direct information to the underlying chemical processes responsible for the setting of the cement.

Alternatively, differential scanning calorimetry (DSC) may be used to study the setting of MTA by measuring the heat evolved (ie, the exothermic heat) during the early stages as well as by monitoring the reaction products that formed via their decomposition upon heating. - It is through this testing methodology that more objective data on MTA's

Journal of Endodontics, Vol. 41, No. 1 (January 2015): pg. 88-91. DOI. This article is (c) Elsevier and permission has been granted for this version to appear in e-Publications@Marquette. Elsevier does not grant permission for this article to be further copied/distributed or hosted elsewhere without the express permission from Elsevier. 
setting may be acquired. When reacted MTA is heated, it is possible to calculate the quantity of product formed from the quantity of heat required to decompose it. Decomposition of $\mathrm{C}-\mathrm{S}-\mathrm{H}$ occurs via dehydration at around $115^{\circ}-125^{\circ} \mathrm{C}$, whereas $\mathrm{Ca}(\mathrm{OH}) 2$ decomposes to $\mathrm{CaO}$ (and $\mathrm{H}_{2} \mathrm{O}$ ) via dehydroxylation at around $440^{\circ}-580^{\circ} \mathrm{C} . \underline{5,6}$ Other reactants and products may also decompose at certain temperatures, but in Portland cement the degree of hydration is indicated by the quantity of $\mathrm{Ca}(\mathrm{OH})_{2}$ formed. 6

To improve MTA's setting time, many investigations have described MTA preparations with various additives. $\frac{12-25}{}$ Commendably, many of these studies also examined if the additives had effects on various physical properties. Although they indicated further studies were required, 1 study cautiously recommended using either 5\% calcium chloride $\left(\mathrm{CaCl}_{2}\right)$ or sodium hypochlorite $(\mathrm{NaOCl})$ gel in place of water when mixing MTA to be used in single-visit endodontic procedures. $\frac{12}{}$ However, although maintenance or improvement in physical properties of MTA with additives is important, the effect those additives have on setting reaction product formation has been ignored. One should recognize that the bioactivity of MTA is attributed to hydration of the powder causing $\mathrm{Ca}^{+2}$ dissolution and diffusion, reaction product formation (C-S-H and $\left.\mathrm{Ca}[\mathrm{OH}]_{2}\right)$, and further reactions resulting in apatite formation. $\frac{3,26,27}{2 t}$ is conceivable that any changes to the setting reaction and reaction product formation may impact the formation of this bioactive layer. With this in mind, the objective of this study was to examine the effect additives have on MTA's setting time and setting reaction using DSC.

\section{Materials and Methods}

In a 3:1 (powder:liquid) mixture, MTA powder (ProRoot White; Dentsply Tulsa Dental, Johnson City, TN) was prepared with distilled water (control), phosphate buffered saline (PBS; Fisher Scientific, Pittsburgh, PA), 5\% $\mathrm{CaCl}_{2}$ (Fisher Scientific [prepared as a solution by dissolving $\mathrm{CaCl}_{2}$ in distilled water at a $5 \%$ concentration]), $3 \% \mathrm{NaOCl}$ (ChlorCid V; Ultradent Products, South Jordan, UT), or lidocaine (2\% Xylocaine Dental with epinephrine 1:100,000; Novocol Pharmaceutical, Cambridge, Ontario, Canada). The 3:1 (powder:liquid) mixture was applied to all preparations to standardize proportions. The mixtures were transferred to preweighed 40- $\mu \mathrm{L}$ aluminum crucibles (Mettler-Toledo, Columbus, $\mathrm{OH}$ ) and weighed in an analytical balance with the amount of mixture in each calculated. Each mixture group was tested at the following time points: immediately after, 1 day, 1 week, 1 month, and 3 months ( $n=9 /$ mixture group/time); individual specimens were only tested once. With the exception of the immediate specimens, the groups were

Journal of Endodontics, Vol. 41, No. 1 (January 2015): pg. 88-91. DOI. This article is (c) Elsevier and permission has been granted for this version to appear in e-Publications@Marquette. Elsevier does not grant permission for this article to be further copied/distributed or hosted elsewhere without the express permission from Elsevier. 
stored in an incubator at $37^{\circ} \mathrm{C}$ with $100 \%$ humidity until their prescribed time of analysis (1 day, 1 week, and so on).

Each crucible of the immediate specimens was fitted with a lid to prevent water evaporation and placed in the DSC (Model 822e, Mettler-Toledo) for an isothermal scan at $37^{\circ} \mathrm{C}$ for 8 hours to analyze any exothermic peaks associated with setting. As a reference during measuring, an empty 40- $\mu \mathrm{L}$ aluminum crucible was used. After the 8-hour isothermal scan, this immediate specimen was weighed again, and the lid was pierced to allow for equilibration of pressure and release of volatile products upon heating (ie, water evaporation). The crucible was placed back on the DSC sensor for analysis by a dynamic scan from $37^{\circ} \mathrm{C} \rightarrow 640^{\circ} \mathrm{C}$ at $10^{\circ} \mathrm{C} / \mathrm{min}$. (Because the dynamic scan was at the 8-hour mark in the immediate specimens, it is later termed "8 hour" for data comparison.) For the remaining groups, at their designated time frames, the test samples were weighed and fitted with a pierced lid before the same dynamic DSC evaluation $\left(37^{\circ} \mathrm{C} \rightarrow 640^{\circ} \mathrm{C}\right)$. As mentioned previously, the dynamic thermal scan is used to quantify reaction product formation via the enthalpy (J/g) associated with their decomposition upon heating. All resulting DSC thermograms were evaluated by the DSC manufacturer's software (STARe, Mettler-Toledo). Both the time of setting of exothermic peak(s) and enthalpy associated with $\mathrm{Ca}(\mathrm{OH})_{2}$ decomposition computed via integration of the endothermic peak were determined from the respective isothermal and dynamic thermograms. $\mathrm{Ca}(\mathrm{OH})_{2}$ decomposition enthalpy was statistically analyzed with 2-way analysis of variance with the mixture group and time as factors with a post hoc Tukey studentized range (honest significant difference) test when indicated at $\alpha=0.05$ (SAS, Cary, NC).

\section{Results}

The isothermal DSC evaluations resulted in thermograms with exothermic peaks identified across an 8 -hour period at $37^{\circ} \mathrm{C}$. The time, number, and height/area of exothermic peaks associated with setting varied across additive mixture groups. The control, PBS, and lidocaine groups exhibited 2 exothermic peaks averaging $44 \pm 12$ minutes, $49 \pm 20$ minutes, and $36 \pm 8$ minutes for the first, less intense peak and a second peak averaging $343 \pm 57$ minutes, $355 \pm 43$ minutes, and $316 \pm 58$ minutes, respectively. The $\mathrm{NaOCl}$ group's thermograms showed an average peak of $49 \pm 16$ minutes, with 2 instances showing an additional peak at 317 and 343 minutes. The $\mathrm{CaCl}_{2}$ group had only 1 exothermic peak occurring on average at $101 \pm 11$ minutes (Fig. 1).

Journal of Endodontics, Vol. 41, No. 1 (January 2015): pg. 88-91. DOI. This article is (c) Elsevier and permission has been granted for this version to appear in e-Publications@Marquette. Elsevier does not grant permission for this article to be further copied/distributed or hosted elsewhere without the express permission from Elsevier. 


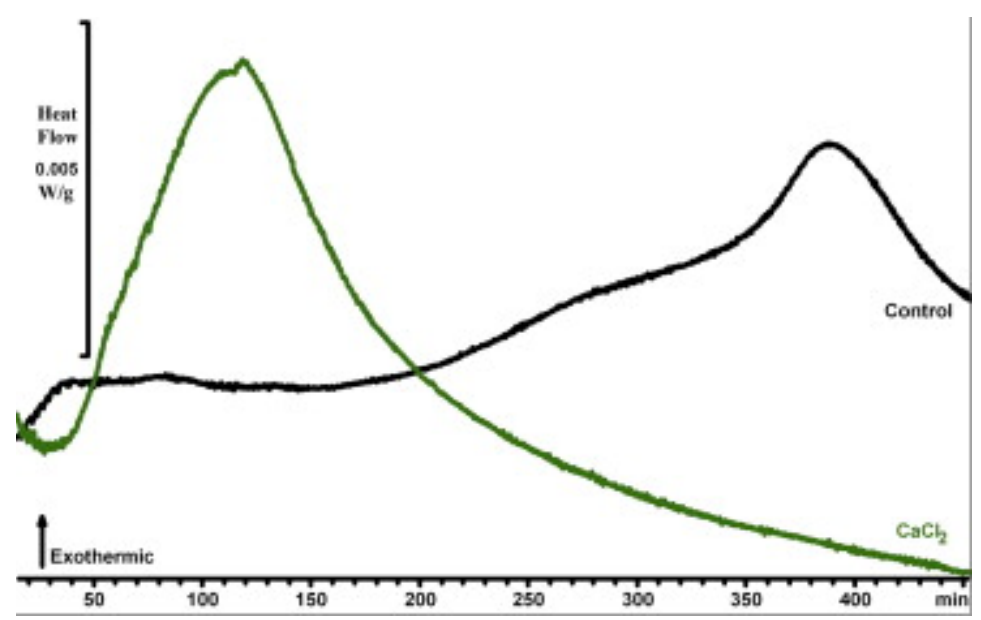

Figure 1. Comparison of exothermic setting peaks during isothermal DSC.

For the DSC thermograms resulting from the dynamic scan, endothermic peaks were identified across a temperature range of $37^{\circ} \mathrm{C} \rightarrow 640^{\circ} \mathrm{C}$. Figure 2 displays thermograms among the groups at 1 week. A comparison of thermograms across additives showed qualitative differences for $\mathrm{NaOCl}$ in which more endothermic peaks were present in a distinct pattern across all time frames, specifically from $160^{\circ} \mathrm{C}-340^{\circ} \mathrm{C}$. For all groups and time frames, an endothermic peak appeared between $100^{\circ} \mathrm{C}$ and $150^{\circ} \mathrm{C}$ associated with the liberation of water and dehydration of the $\mathrm{C}-\mathrm{S}-\mathrm{H}$ reaction product. $\frac{5-7}{}$ However, it should be noted that ettringite produced from the tricalcium aluminate component of MTA powder also dehydrates around $120^{\circ}-130^{\circ} \mathrm{C}, 6$ and may be obscured by the much more abundant $\mathrm{C}-\mathrm{S}$-H dehydration. For the 8-hour and 1-day group, an endothermic peak was identified around $160^{\circ}-200^{\circ} \mathrm{C}$ because of the dehydration of gypsum $\frac{5-7}{}$ (not visible in the 1-week thermogram in Fig. 2). The final endothermic peak presented from $450^{\circ}-550^{\circ} \mathrm{C}$ and is associated with the dehydroxylation of $\mathrm{Ca}(\mathrm{OH}) 2 . \underline{5-7}$ The enthalpy $(\mathrm{J} / \mathrm{g})$ attributed to $\mathrm{Ca}(\mathrm{OH})_{2}$ decomposition, which is proportional to the amount of $\mathrm{Ca}(\mathrm{OH}) 2$ present, analyzed via 2-way analysis of variance/Tukey honest significant difference test indicated it followed the following pattern $(P<.05)$ : control $=\mathrm{CaCl}_{2}>\mathrm{PBS}>$ lidocaine $>\mathrm{NaOCl}$ among the mixtures and 1 week $>1$ day $=1$ month $>3$ months $>8$ hours among times. Because of a significant $(P<.0001)$ interaction between the additive/mixture group and time, a general linear model procedure using the method of least squares and a Tukey-Kramer adjustment for multiple comparisons was used, and results are presented in Table 1 . At 8 hours after mixing, $\mathrm{CaCl}_{2}$ had the greatest calcium hydroxide enthalpy, which implies the greatest $\mathrm{Ca}(\mathrm{OH})_{2}$ reaction product formation. Across all groups, $\mathrm{Ca}(\mathrm{OH})_{2}$ reaction product formation peaked 1 week after mixing. Among the groups at 1 week, the control resulted in the greatest enthalpy, whereas in comparison, $\mathrm{NaOCl}$ at 1 week resulted in the lowest

Journal of Endodontics, Vol. 41, No. 1 (January 2015): pg. 88-91. DOI. This article is (c) Elsevier and permission has been granted for this version to appear in e-Publications@Marquette. Elsevier does not grant permission for this article to be further copied/distributed or hosted elsewhere without the express permission from Elsevier. 
amount of $\mathrm{Ca}(\mathrm{OH})_{2}$. Finally, at 3 months, all groups besides the control group showed a significant decrease in $\mathrm{Ca}(\mathrm{OH})_{2}$ decomposition enthalpy.

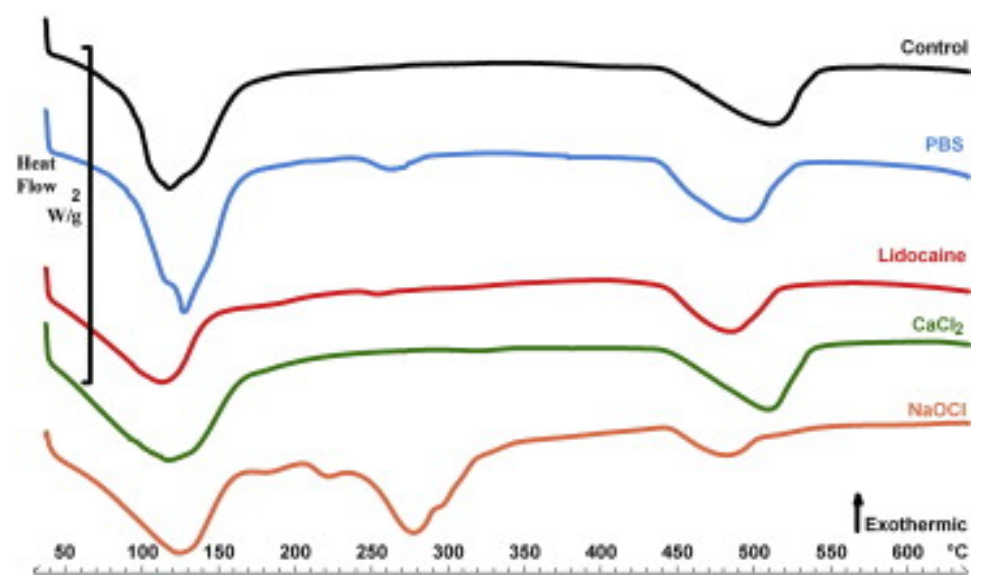

Figure 2. Comparative DSC thermograms of MTA mixed with different additives 1 week after mixing. The endothermic peaks around $100^{\circ} \mathrm{C}-150^{\circ} \mathrm{C}$ and $450^{\circ} \mathrm{C}-550^{\circ} \mathrm{C}$ are associated with the liberation of water/dehydration of calcium silicate hydrates and dehydroxylation of calcium hydroxide reaction products, respectively.

Table 1. Calcium Hydroxide Reaction Product Formation via Decomposition Enthalpy as Determined by Differential Scanning Calorimetry*

\begin{tabular}{lccccc}
\multicolumn{1}{c}{ Group } & \multicolumn{5}{c}{$\mathrm{Ca}(\mathrm{OH})_{2}$ decomposition enthalpy $\left.\mathrm{J} / \mathrm{g}\right)$} \\
& $\mathbf{8}$ hours & $\mathbf{1}$ day & 1 week & 1 month & 3 months \\
Control & $22.5 \pm 10.6^{\mathrm{Bc}}$ & $70.1 \pm 17.5^{\mathrm{Bb}}$ & $138.5 \pm 13.5^{\mathrm{Aa}}$ & $98.8 \pm 8.6^{\mathrm{Aa}}$ & $98.8 \pm 13.3^{\mathrm{Aa}}$ \\
$\mathrm{PBS}$ & $12.4 \pm 11.9^{\mathrm{Bc}}$ & $93.9 \pm 16.1^{\mathrm{Ab}}$ & $116.8 \pm 12.4^{\mathrm{Ba}}$ & $82.1 \pm 14.4^{\mathrm{Ab}}$ & $81.4 \pm 15.9^{\mathrm{Ab}}$ \\
Lidocaine & $12.3 \pm 5.8^{\mathrm{Bc}}$ & $82.0 \pm 4.0^{\mathrm{Aba}}$ & $87.2 \pm 6.6^{\mathrm{Ca}}$ & $59.6 \pm 11.7^{\mathrm{Bb}}$ & $32.4 \pm 8.4^{\mathrm{Cc}}$ \\
$\mathrm{CaCl}_{2}$ & $81.7 \pm 10.4^{\mathrm{Ab}}$ & $100.3 \pm 8.6^{\mathrm{Aab}}$ & $117.4 \pm 6.9^{\mathrm{Ba}}$ & $96.0 \pm 11.0^{\mathrm{Ab}}$ & $57.2 \pm 15.8^{\mathrm{Bc}}$ \\
$\mathrm{NaOCl}$ & $20.2 \pm 14.4^{\mathrm{Bab}}$ & $24.1 \pm 8.0^{\mathrm{Cab}}$ & $39.2 \pm 6.8^{\mathrm{Da}}$ & $22.9 \pm 8.3^{\mathrm{Cab}}$ & $16.8 \pm 8.2^{\mathrm{Cb}}$
\end{tabular}

$\mathrm{CaCl}_{2}$, calcium chloride; $\mathrm{NaOCl}$, sodium hypochlorite; PBS, phosphate buffered saline.

Two-way analysis of variance/Tukey honest significant difference test indicated significant $(P<.0001)$ differences among additive/mixture group and time. Because of a significant $(P<.0001)$ interaction between group and time, a general linear model procedure using the method of least squares and a Tukey-Kramer adjustment for multiple comparisons was used. Different superscript capital letters denote significant differences $(P<.05)$ within each time period with respect to the different groups. Different superscript small letters denote significant differences $(P<.05)$ between time periods for a given group.

$*$ The group name, besides the control, indicates the additive used in mixing MTA.

\section{Discussion}

The isothermal DSC results for MTA mixed with water as well as that with PBS and lidocaine displayed 2 exothermic peaks: an early relatively small peak and a later more

Journal of Endodontics, Vol. 41, No. 1 (January 2015): pg. 88-91. DOI. This article is (c) Elsevier and permission has been granted for this version to appear in e-Publications@Marquette. Elsevier does not grant permission for this article to be further copied/distributed or hosted elsewhere without the express permission from Elsevier. 
intense peak. Hydration of tricalcium silicate is thought to occur in 5 stages with exothermic peaks associated with the initial particle dissolution during the first stage (preinduction) and then in the third stage (accelerating period) highlighted by a rapid hydration reaction of tricalcium silicate to form the reaction products. $\underline{6}$ The preinduction stage is expected within minutes of mixing. The reaction rate of dicalcium silicate hydration is slower than that of tricalcium silicate, so the former may appear at later times. Thus, it is not definitive what events the exothermic peaks in MTA correspond with, and other analytical techniques are required for further elucidation. Still, the point of maximum exothermic heat generation has been used as an indication of the setting time of various dental cements, $\underline{28,29}$ and for tricalcium silicate hydration, the initial set corresponds to the start of the accelerating period, and the final set is at the maximum heat generation. $\underline{6}$ It is apparent from observation of the $\mathrm{CaCl}_{2}$ isothermal results that the main exothermic peak occurs earlier and the enthalpy of the reaction is greater than the control MTA ( $\underline{\text { Fig. } 1}$ ). $\mathrm{CaCl}_{2}$ has a similar effect on the hydration of tricalcium silicate in Portland cement. $\underline{6}$ The effect of the other additives on hastening setting was not notable and is further confirmed with the dynamic DSC results at the 8-hour mark that show the formation of $\mathrm{Ca}(\mathrm{OH}) 2$ was significantly greater in the $\mathrm{CaCl}_{2}$ group compared with all others, but no other differences were noted. Comparatively, the extent of exothermic reaction/heat generation in MTA is less than $1 / 10$ of the exothermic reaction of glass-ionomer acid-base reactions; $\underline{29}$ thus, no concern for thermally induced damage to tooth structure is necessary.

Calcium hydroxide decomposition enthalpy results for all mixtures show that even though MTA may be considered set within 6 hours, continued maturation occurs over time as evidenced by the greatest $\mathrm{Ca}(\mathrm{OH})_{2}$ production at 1 week, which was consistent with previous research. -7 The reduction in $\mathrm{Ca}(\mathrm{OH})_{2}$ beyond 1 week has been shown before ${ }^{7}$ and is associated with penetration of $\mathrm{CO}_{2}$ from the atmosphere reacting with the $\mathrm{Ca}(\mathrm{OH})_{2}$ to form $\mathrm{CaCO}_{3} .4$ This conversion is also possible in vivo although it remains conjecture at present. 4 Unfortunately, the high temperature range of the DSC used in the present investigation was limited and was not able to determine the $\mathrm{CaCO}_{3}$ decomposition enthalpy at $750^{\circ} \mathrm{C}-850^{\circ} \mathrm{C} . \underline{5,6}$

The dynamic DSC results showed that MTA when mixed with certain additives alters $\mathrm{Ca}(\mathrm{OH})_{2}$ production. At 1 day and beyond, MTA mixed with $\mathrm{NaOCl}$ produced significantly less $\mathrm{Ca}(\mathrm{OH})_{2}$ than the control, whereas the lidocaine group was significantly less than the control at 1 week and beyond. Alternatively, when $\mathrm{CaCl}_{2}$ was used, the amount of $\mathrm{Ca}(\mathrm{OH})_{2}$ produced was greater than the control early on ( $\leq 1$ day) but was not as much long-term ( $\geq 1$ week). Hong et al $\underline{30}$ showed 30 minutes of $\mathrm{NaOCl}$ exposure to MTA 10 minutes after mixing had a detrimental effect on the formation of $\mathrm{Ca}(\mathrm{OH})_{2}$ when viewed 2 days after

Journal of Endodontics, Vol. 41, No. 1 (January 2015): pg. 88-91. DOI. This article is (c) Elsevier and permission has been granted for this version to appear in e-Publications@Marquette. Elsevier does not grant permission for this article to be further copied/distributed or hosted elsewhere without the express permission from Elsevier. 
setting. However, the same exposure to MTA mixed with $\mathrm{CaCl}_{2}$ showed greater $\mathrm{Ca}(\mathrm{OH})_{2}$ crystal growth compared with regularly mixed MTA. Both occurrences are consistent with the results of this study, specifically that $\mathrm{NaOCl}$ inhibits $\mathrm{Ca}(\mathrm{OH})_{2}$ formation and $\mathrm{CaCl}_{2}$ accelerates the setting reaction in the early stages/days. Besides reduced $\mathrm{Ca}(\mathrm{OH})_{2}$ decomposition, the thermogram for MTA mixed with $\mathrm{NaOCl}$ showed additional peaks between $160^{\circ} \mathrm{C}$ and $340^{\circ} \mathrm{C}$ that indicate another reaction product likely formed in this mixture, perhaps at the expense of $\mathrm{Ca}(\mathrm{OH})_{2}$; further analytical techniques are required to determine its composition. The formation of other compounds when MTA is mixed with $\mathrm{NaOCl}$ is important when one considers that the bioactivity of MTA is associated with $\mathrm{Ca}^{+2}$ dissolution from cement powder components that is then intertwined with $\mathrm{Ca}(\mathrm{OH})_{2}$ formation. $\mathrm{Ca}^{+2}$ then reacts with phosphate (if present in surrounding solution), producing a uniform thickness of apatite at 7 days. $\underline{26,27}$

As mentioned earlier, even if physical properties are maintained or enhanced when MTA is mixed with additives, will it possess equivalent biological properties?

Unfortunately, limited studies are available to address this. Jafarnia et al $\underline{31}$ showed that MTA mixed with $\mathrm{NaOCl}$ decreased fibroblast viability when freshly mixed but not after allowing it to set for 1 day. Alternatively, MTA mixed with $5 \% \mathrm{CaCl}_{2}$, saline, or lidocaine had similar cell viability compared with MTA mixed with water. However, MTA mixed with $10 \% \mathrm{CaCl}_{2}$ (added as a powder component) decreased cell viability and decreased cell attachment. $\frac{32}{}$ Although cytotoxicity testing determines the reaction to a material of a cellular level, in vivo evaluation in living systems may provide greater scrutiny to the overall biocompatibility. $\underline{33}$ Research on the biocompatibility of MTA with additives has been divided. A rat model investigating MTA-filled osteotomies found no difference in the inflammatory response when MTA was mixed with water or $\mathrm{CaCl}_{2} . \underline{33}$ Pulpotomies in dogs experienced similar mineralized tissue bridging between white MTA and white MTA with $\mathrm{CaCl}_{2}$ added to the powder component at $10 \% \cdot \underline{34}$ Contrastingly, there was greater inflammation and necrosis with lesser calcified bridge formation when $\mathrm{MTA} / \mathrm{CaCl}_{2}$ compared with MTA/water was used for pulp capping in dogs although the differences were not statistically significant. $\underline{35}$ Overall, with the possible exception of $\mathrm{CaCl}_{2}$, evidence is absent to suggest MTA mixed with additives, especially those that form less of the typical reaction products as shown in the present study, will provide a similar biological response even if some physical properties are similar or improved. Further animal or human clinical studies are needed to fully evaluate the biological response to MTA with accelerant additives. Looking forward, for MTA as well as similar calcium silicate-based and other dental materials, consideration of the chemistry of the setting reaction is needed when certain additives are added after the manufacturing process.

Journal of Endodontics, Vol. 41, No. 1 (January 2015): pg. 88-91. DOI. This article is (c) Elsevier and permission has been granted for this version to appear in e-Publications@Marquette. Elsevier does not grant permission for this article to be further copied/distributed or hosted elsewhere without the express permission from Elsevier. 
NOT THE PUBLISHED VERSION; this is the author's final, peer-reviewed manuscript. The published version may be accessed by following the link in the citation at the bottom of the page.

\section{Acknowledgments}

The authors wish to thank Dr Jessica Pruszynski of the Medical College of Wisconsin for assistance with the statistical analysis.

The authors deny any conflicts of interest related to this study.

\section{References}

1S.J. Lee, M. Monsef, M. Torabinejad Sealing ability of a mineral trioxide aggregate for repair of lateral root perforations J Endod, 19 (1993), pp. 541-544

2M. Torabinejad, N. Chivian Clinical applications of mineral trioxide aggregate J Endod, 25 (1999), pp. 197-205

3M. Parirokh, M. Torabinejad Mineral trioxide aggregate: a comprehensive literature review-part III: clinical applications, drawbacks, and mechanism of action J Endod, 36 (2010), pp. 400-413

4B.W. Darvell, R.C. Wu "MTA"-an hydraulic silicate cement: review update and setting reaction Dent Mater, 27 (2011), pp. 407-422

5J.I. Bhatty A review of the application of thermal analysis to cement-admixture systems Thermochimica Acta, 189 (1991), pp. 313-350

6V.S. Ramachandran, R.M. Paroli, J.J. Beaudoin, A.H. Delgado Handbook of Thermal Analysis of Construction Materials Noyes Publications/William Andrew Publishing, Norwich, NY (2003)

${ }_{7}^{7}$ S.C. Chedella, D.W. Berzins A differential scanning calorimetry study of the setting reaction of MTA Int Endod J, 43 (2010), pp. 509-518

8. Camilleri Characterization of hydration products of mineral trioxide aggregate Int Endod J, 41 (2008), pp. 408-417

9M. Torabinejad, C.U. Hong, F. McDonald, T.R. Pitt Ford Physical and chemical properties of a new root-end filling material J Endod, 21 (1995), pp. 349-353

10H.K. Chng, I. Islam, A.U. Yap, et al. Properties of a new root-end filling material J Endod, 31 (2005), pp. 665668

11I. Islam, H.K. Chng, A.U. Yap Comparison of the physical and mechanical properties of MTA and Portland cement JEndod, 32 (2006), pp. 193-197

12P. Kogan, J. He, G.N. Glickman, I. Watanabe The effects of various additives on setting properties of MTA J Endod, 32 (2006), pp. 569-572

13 T.H. Huang, M.Y. Shie, C.T. Kao, S.J. Ding The effect of setting accelerator on properties of mineral trioxide aggregate JEndod, 34 (2008), pp. 590-593

14S.J. Ding, C.T. Kao, M.Y. Shie, et al. The physical and cytological properties of white MTA mixed with Na2HPO4 as an accelerant $J$ Endod, 34 (2008), pp. 748-751

15E.A. Bortoluzzi, N.J. Broon, M.A. Duarte, et al. The use of a setting accelerator and its effect on $\mathrm{pH}$ and calcium ion release of mineral trioxide aggregate and white Portland cement J Endod, 32 (2006), pp. 11941197

16B.S. Ber, J.F. Hatton, G.P. Stewart Chemical modification of ProRoot MTA to improve handling characteristics and decrease setting time JEndod, 33 (2007), pp. 1231-1234

17K.B. Wiltbank, S.A. Schwartz, W.G. Schindler Effect of selected accelerants on the physical properties of mineral trioxide aggregate and Portland cement JEndod, 33 (2007), pp. 1235-1238

Journal of Endodontics, Vol. 41, No. 1 (January 2015): pg. 88-91. DOI. This article is (c) Elsevier and permission has been granted for this version to appear in e-Publications@Marquette. Elsevier does not grant permission for this article to be further copied/distributed or hosted elsewhere without the express permission from Elsevier. 
NOT THE PUBLISHED VERSION; this is the author's final, peer-reviewed manuscript. The published version may be accessed by following the link in the citation at the bottom of the page.

18S.T. Hong, K.S. Bae, S.H. Baek, et al. Microleakage of accelerated mineral trioxide aggregate and Portland cement in an in vitro apexification model J Endod, 34 (2008), pp. 56-58

19E.A. Bortoluzzi, N.J. Broon, C.M. Bramante, et al. The influence of calcium chloride on the setting time, solubility, disintegration, and $\mathrm{pH}$ of mineral trioxide aggregate and white Portland cement with a radiopacifier J Endod, 35 (2009), pp. 550-554

20M.G. Gandolfi, F. Iacono, K. Agee, et al. Setting time and expansion in different soaking media of experimental accelerated calcium-silicate cements and ProRoot MTA Oral Surg Oral Med Oral Pathol Oral Radiol Endod, 108 (2009), pp. e39-e45

21 S.C. Hsieh, N.C. Teng, Y.C. Lin, et al. A novel accelerator for improving the handling properties of dental filling materials J Endod, 35 (2009), pp. 1292-1295

22A.Z. AlAnezi, Q. Zhu, Y.H. Wang, et al. Effect of selected accelerants on setting time and biocompatibility of mineral trioxide aggregate (MTA) Oral Surg Oral Med Oral Pathol Oral Radiol Endod, 111 (2011), pp. $122-127$

23 D.Y. Ji, H.D. Wu, S.C. Hsieh, et al. Effects of a novel hydration accelerant on the biological and mechanical properties of white mineral trioxide aggregate J Endod, 37 (2011), pp. 851-855

${ }^{24}$ B.N. Lee, Y.C. Hwang, J.H. Jang, et al. Improvement of the properties of mineral trioxide aggregate by mixing with hydration accelerators J Endod, 37 (2011), pp. 1433-1436

25 K.S. Appelbaum, J.T. Stewart, G.R. Hartwell Effect of sodium fluorosilicate on the properties of Portland cement J Endod, 38 (2012), pp. 1001-1003

26 N.K. Sarkar, R. Caicedo, P. Ritwik, et al. Physicochemical basis of the biologic properties of mineral trioxide aggregate JEndod, 31 (2005), pp. 97-100

27M.G. Gandolfi, P. Taddei, A. Tinti, C. Prati Apatite-forming ability (bioactivity) of ProRoot MTA Int Endod J, 43 (2010), pp. 917-929

28 J.F. McCabe, H.J. Wilson The use of differential scanning calorimetry for the evaluation of dental materials. I. Cements, cavity lining materials and anterior restorative materials J Oral Rehabil, 7 (1980), pp. 103110

299.K. Khalil, E.D. Atkins Investigation of glass-ionomer cements using differential scanning calorimetry J Mater Sci Mater Med, 9 (1998), pp. 529-533

30S.T. Hong, K.S. Bae, S.H. Baek, et al. Effects of root canal irrigants on the push-out strength and hydration behavior of accelerated mineral trioxide aggregate in its early setting phase J Endod, 36 (2010), pp. 1995-1999

31B. Jafarnia, J. Jiang, J. He, et al. Evaluation of cytotoxicity of MTA employing various additives Oral Surg Oral Med Oral Pathol Oral Radiol Endod, 107 (2009), pp. 739-744

32J.Y. Kang, B.N. Lee, H.J. Son, et al. Biocompatibility of mineral trioxide aggregate mixed with hydration accelerators JEndod, 39 (2013), pp. 497-500

33 R.P. McNamara, M.A. Henry, W.G. Schindler, K.M. Hargreaves Biocompatibility of accelerated mineral trioxide aggregate in a rat model $J$ Endod, 36 (2010), pp. 1851-1855

34E.A. Bortoluzzi, N.J. Broon, C.M. Bramante, et al. Mineral trioxide aggregate with or without calcium chloride in pulpotomy $J$ Endod, 34 (2008), pp. 172-175

35M. Parirokh, S. Asgary, M.J. Eghbal, et al. A comparative study of using a combination of calcium chloride and mineral trioxide aggregate as the pulp-capping agent on dogs' teeth J Endod, 37 (2011), pp. 786-788

Journal of Endodontics, Vol. 41, No. 1 (January 2015): pg. 88-91. DOI. This article is (c) Elsevier and permission has been granted for this version to appear in e-Publications@Marquette. Elsevier does not grant permission for this article to be further copied/distributed or hosted elsewhere without the express permission from Elsevier. 